\title{
Growth factors and extracellular matrix proteins in interactions of cumulus-oocyte complex, spermatozoa and oviduct
}

\author{
R. Einspanier ${ }^{1}$, C. Gabler ${ }^{1}$, B. Bieser ${ }^{1}$, A. Einspanier ${ }^{2}$, \\ B. Berisha ${ }^{1}$, M. Kosmann ${ }^{1}$, K. Wollenhaupt ${ }^{3}$ and D. Schams ${ }^{1}$ \\ ${ }^{1}$ Institute of Phy/siology, TU Munich, D-85350 Freising, Germany; ${ }^{2}$ German Primate Center, \\ D-37077 Göttingen, Germany; and ${ }^{3}$ FBN, D-18196 Dummerstorf, Germany
}

\begin{abstract}
The expression and localization of selected growth factor systems and extracellular matrix (ECM) components that may influence oocyte maturation and fertilization within the mammalian oviduct are reported. Fibroblast growth factor (FGF) and vascular endothelial growth factor (VEGF) systems could be detected by use of RT-PCR, RNase protection assay (RPA) and immunohistochemistry in bovine follicles, bovine cumulus-oocyte complexes (COC) and bovine and marmoset oviducts. Two different subtypes of the FGF receptor (FGFR-1 and -2) were identified in distinct cell types, indicating a functional difference. A complete epidermal growth factor (EGF) system was found in the porcine, but not in the bovine, oviduct. There were additional differences between bovine and primate oviducts: FGF-1/2 and FGFR were increased in the marmoset around ovulation, in contrast to an increase in FGF-1 in the cow. Immunohistochemistry revealed accumulation and storage of FGF and VEGF on the surface of the epithelium, possibly due to their binding property on heparanglycoproteins. Other ECM components, matrix metalloproteinase 1 (MMP-1) and tissue inhibitor of metalloproteinase 1 (TIMP-1), were found to be modulated in the ovarian follicle, $C O C$ and oviduct during the cycle. An oviduct-mediated depletion of sperm surface proteins (BSP1-3) was discovered as well as a sperm-induced novel oviductal mRNA related to an anti-oxidant protein family. Associated systems of growth factors and ECM components can be suggested as paracrine or autocrine mediators during fertilization in a species-, cycle- and tissue-dependent manner.
\end{abstract}

\section{The Oviduct as the Site of Fertilization and Early Embryonic Development}

The central events of fertilization take place in the environment of the mammalian oviduct, which appears to be controlled by gonadotrophins, sex steroids or both. Such hormonal actions may be sustained by a paracrine action mediated by growth factors or extracellular matrix components (ECM) as in the development of mammalian ovarian follicle (Monniaux et al., 1997). These multifunctional growth factors are known to both stimulate and inhibit cell proliferation and differentiation (Sporn and Roberts, 1988) and therefore represent an important class of substances in regulating cell-cell interactions. Known as the organ of limited storage and final capacitation of the sperm (Lefebvre et al., 1995), the oviduct has attracted much scientific interest. The nature of oestrogen-dependent glycoproteins has been analysed for humans, primates and ruminants (Donnelly et al., 1991; Arias et al., 1994; DeSouza and Murray 1995; Sendai et al,, 1995) and indicates that they bind to the oocyte or spermatozoa.

Embryotrophic factors and mitogens, such as growth factors, are present in variable amounts in the oviduct (Gandolfi et al., 1989) and Ellington (1991) provided a detailed review on this important reproductive organ. This review deals with the expression of bioactive proteins in bovine ovarian 


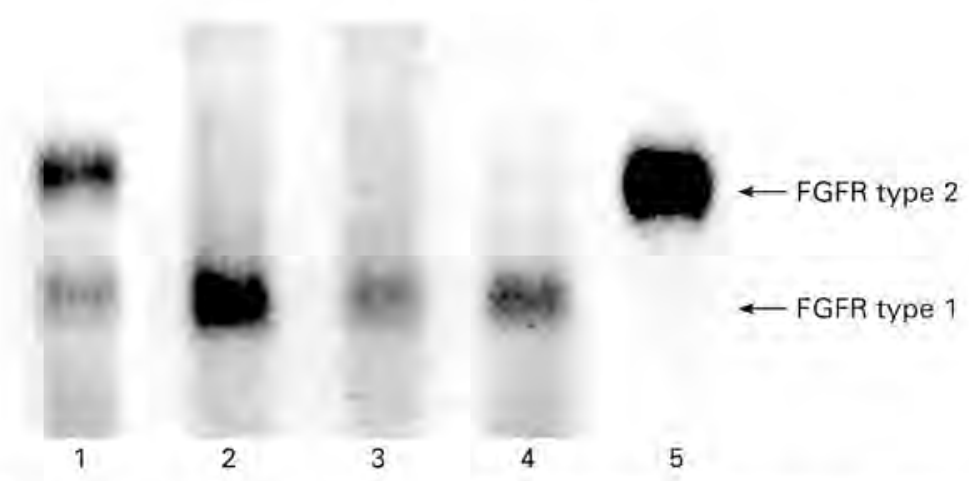

Fig. 1. Detection of fibroblast growth factor receptor (FGFR) subtype 1 and 2 in bovine ovarian thecal tissue (1), granulosal cells before LH (2), granulosal cells after LH (3), matured cumulus-oocyte complexes (COC) (4) and oviductal epithelium (5). Uniform RT-PCR products were separated by intercalating agarose electrophoresis depending on sequence differences.

follicles, cumulus-oocyte complexes (COC) and mammalian oviducts in relation to their developmental state. Furthermore, the initial interactions between the oviduct and spermatozoa are described.

\section{Protein Expression in Ovarian and Oviductal Cells}

\section{Growth factor systems}

Within the ovarian follicle, at the site of oocyte maturation, a complex network of different growth factors is present, modulating the autocrine and paracrine effects observed under hormonal influence. We elucidated some changes during the maturation of bovine follicles by detecting distinct gene products of the fibroblast growth factor (FGF) and vascular endothelial growth factor (VEGF) system. In thecal tissue, the overall expression of FGF-1, FGF-2, and FGFR was found to be relatively high when compared with that of granulosal cells (Einspanier et al., 1997). FGF-2 mRNA was found in considerable amounts only after the LH surge in granulosal cells in vivo. The same effect could be observed in cumulus cells during in vitro maturation (IVM) of COC which was supported by detection of immunoreactive FGF-2 protein. The complete VEGF system was found in bovine follicles: the ligand and both receptors (flk, flt) were identified in thecal and granulosal cells and, moreover, VEGF protein was increased in follicular fluid just before ovulation. This observation was in agreement with a large increase in VEGF mRNA synthesis found in granulosal cells in vivo after LH. In contrast, cumulus cells surrounding the oocyte contained only low concentration of VEGF transcript after IVM. A second difference between granulosal and cumulus cells is a probable lack of the flk-type receptor in cumulus cells. After applying a gel-retardation technique (Plath et al., 1997) two different types of FGFR were found using a simple electrophoretic separation of specific PCR products. A sole FGFR type 1 was found in granulosal and cumulus cells, the type 2 only in oviductal epithelium, but a mixture of both in thecal tissue (Fig. 1). A functional difference between these receptor types could support their distinct tasks.

The ideal environment for fertilization and early embryonic development is found in the oviduct. Our search for specific growth factors revealed the following details: all components of the FGF and VEGF systems are expressed within the bovine and primate oviduct epithelium. Specifically, a cycle-dependent regulation of the FGF-1 was detected by measuring significantly higher protein concentrations in bovine oviductal flushings during ovulation $\left(5.3 \pm 0.5 \mathrm{ng} \mathrm{ml}^{-1}\right)$ 
compared with the luteal phase $\left(3.5 \pm 0.5 \mathrm{ng} \mathrm{ml}^{-1}\right)$. In parallel, there was an increase in FGF-1 transcripts before ovulation in oviductal cells and for the whole cycle the FGF-2 and FGFR expression appeared to stay constant (Gabler et al, 1997a). VEGF was enriched just before ovulation, as was its flt-type receptor, but expression of the flk-receptor was unchanged during the cycle, indicating an independent regulation of both receptor types within the bovine oviduct. In contrast, when these growth factors were investigated in the marmoset monkey, highest mRNA contents were found during the ovulatory period for all growth factors and their receptors. Likewise, FGF-1, FGF2 and VEGF immunoreactive proteins were mainly found on the epithelial surface of both the bovine and primate oviduct and at the same location as heparan sulfate molecules. This phenomenon will be discussed in the ECM section below. In the cow, we could not find a complete epidermal growth factor (EGF) system, which is known to represent a prominent growth factor in other mammals (Adachi et al, 1995; Wollenhaupt et al, 1997). In contrast, the porcine endometrium and oviduct contain mRNA encoding both ligands (EGF and TGF $\alpha$ ) and the receptor (EGFR). Furthermore, a biologically active endometrial or oviductal EGFR could be demonstrated by ligand binding and EGF-dependent phosphorylation of the receptor protein (Wollenhaupt et al., 1998).

\section{ECM components}

Collagenolytic activity has been shown to be an important process during gonadotrophinmediated follicular rupture in the rabbit (Tadakuma et al., 1993). According to this, MMP-1 expression was below the detection limit in bovine thecal and granulosal cells before the LH surge, but thereafter increased expression in both cell types indicates that they have a role at the time of ovulation. The inhibitor of MMP-1, TIMP-1, reacted in a similar way indicating a fine-tuned proteolytic cascade within the follicle. When in vitro matured COC were sequentially analysed for the expression of MMP-1 and TIMP-1 using zymographic electrophoresis, two proteolytically active enzymes of 55 and $67 \mathrm{kDa}$ were detected, and one of these proteins may be the latent MMP-1 protein (Lauer and Einspanier, 1996a). In parallel, using RT-PCR, we detected increasing MMP-1 transcripts during IVM from $6 \mathrm{~h}$. A similar increase of specific mRNA could be observed for TIMP-1 after $6 \mathrm{~h}$ of maturation, with a relatively stable high expression up to $24 \mathrm{~h}$ of IVM. Parallel cumulus expansion suggested some influences of these proteolytic ECM components.

Heparan sulfate-like molecules could be detected by immunohistology on the surface of bovine and marmoset oviduct epithelial cell layer, as shown by Gabler et al. (1997a, 1998). On this basis, it is possible that heparin-binding proteins like FGF and VEGF could be easily fixed on such structures, changing their biological availability. A longer half-life of these growth factors could result from this process, mediating local effects. In this context, the ECM protease MMP-1 showed increased activity and expression during the luteal phase within the bovine oviduct, possibly contributing to a cellular turnover or reassembly. At the same time, there was a decrease of its inhibitor TIMP-1, but during ovulation a rise of transcript concentrations could be seen (Fig. 2), possibly preventing a matrix degradation during ovulation. However, a second embryo-stimulating effect of TIMP- 1 in the oviduct, as suggested earlier by Satoh et al. (1994), cannot be excluded.

\section{Interactions Between Oviduct and Spermatozoa}

Sperm capacitation takes place not only in the cervix but also continues during passage through the oviduct. Therefore, final maturation of spermatozoa may occur in transit. Furthermore, storage of viable spermatozoa was observed in the isthmus of the oviduct (Hunter, 1995). After exposure of bovine spermatozoa to cultured oviductal epithelial cells or oviductal fluid, we found that three specific proteins were liberated in a time-dependent manner from sperm surfaces. $\mathrm{N}$-terminal characterization of these proteins revealed that they were known bovine seminal proteins BSP1, -2 and -3 (Lauer et al., 1995). Such proteins have high affinities for heparin and can easily react with heparan molecules on the oviductal surface. Furthermore, BSPs can be removed by addition of heparin in vitro, which may explain why heparin has been commonly introduced to bovine sperm 


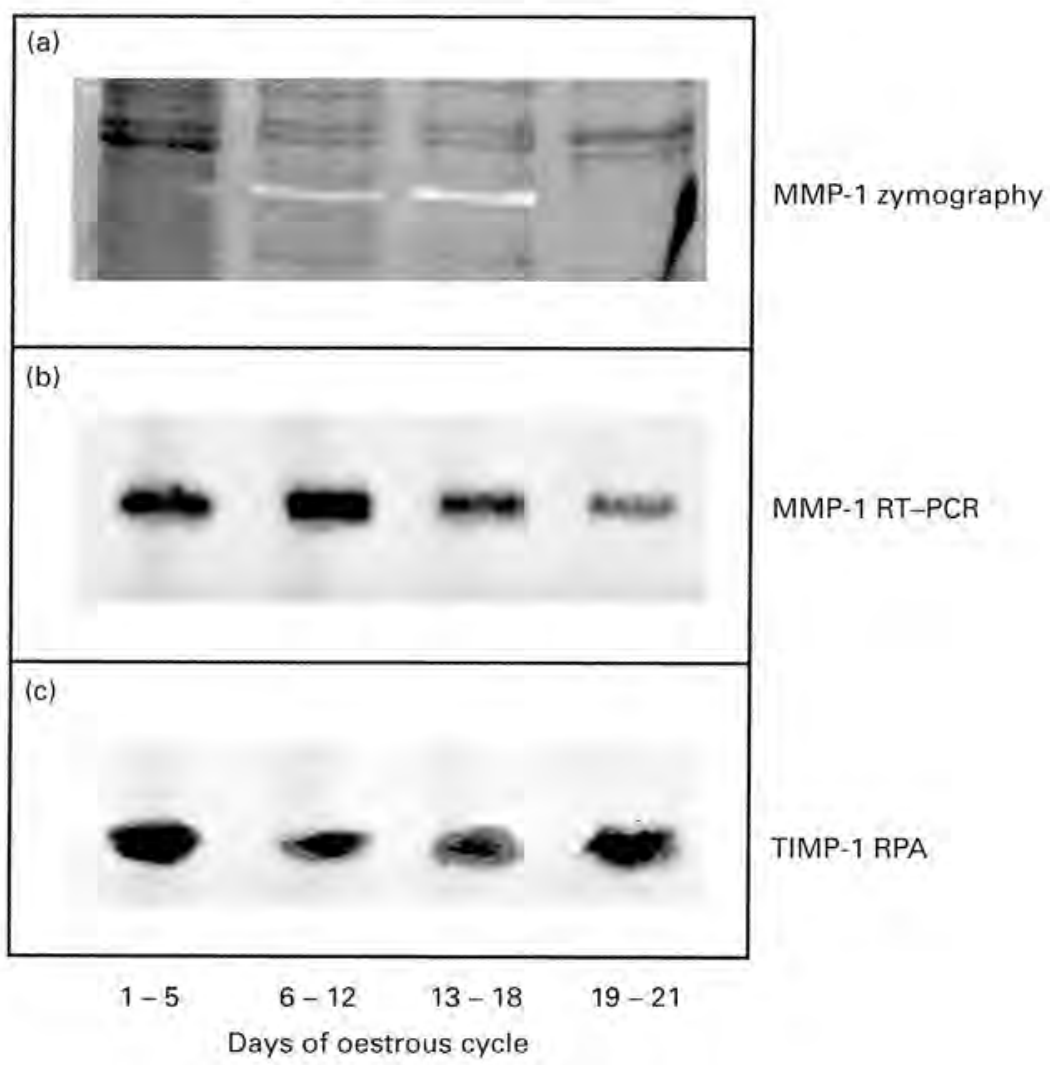

Fig. 2. Analysis of extracellular matrix (ECM) components in bovine oviducts at different stages of the oestrous cycle: presence of matrix metalloproteinase 1 (MMP-1)-like enzymatic activity detected by zymography (a; one of two experiments). Specific mRNAs in epithelial cells were shown by RT-PCR for MMP-1 (b; 37 cycles, one of three experiments) and by RNase protection assay for tissue inhibitor of metalloproteinase 1 (TIMP-1) (c; $30 \mu \mathrm{g}$ total RNA, one of six experiments) as indicated.

capacitation media. In vivo related heparin analogues are found within the oviduct fluid in variable amounts depending on the stage of the ovarian cycle (Lauer and Einspanier, 1996b).

A new random PCR technique (randomly amplified RNA (RAP)-PCR) was used to study new transcripts within the oviductal cell that may be triggered by sperm contact. Such a sperm-induced mRNA of about 440 bases was isolated from cultured oviduct epithelial cells. After cDNA sequencing, the transcript was identified as a new bovine mRNA fragment (EMBL-Ac.nr: Z86040) encoding a protein related to a large anti-oxidant protein family. The deduced amino acid structure of the S5-clone possesses a very high homology (96\%) to a known human protein (ULA06) affiliated to the AhpC/TSA (alkyl-hydroperoxide-reductase/thiol-specific antioxidant) family (Fig. 3). All members of this protein family show properties associated with oxygen-regulating enzyme systems that may be important contributors of embryonic viability; comparable redox systems within the bovine oviduct were reported to be necessary by Harvey and co-workers (1995). 


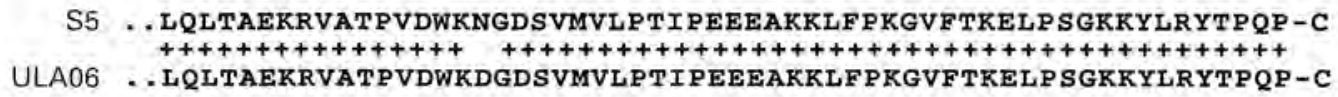

Fig. 3. Sequence comparison of the new sperm-induced oviductal protein $\mathrm{S} 5$ and a known human protein (ULA06) related to a reductase/antioxidant (AhpC/TSA) protein family. The C-terminal part is shown. Homologous amino acids are marked $(+)$.
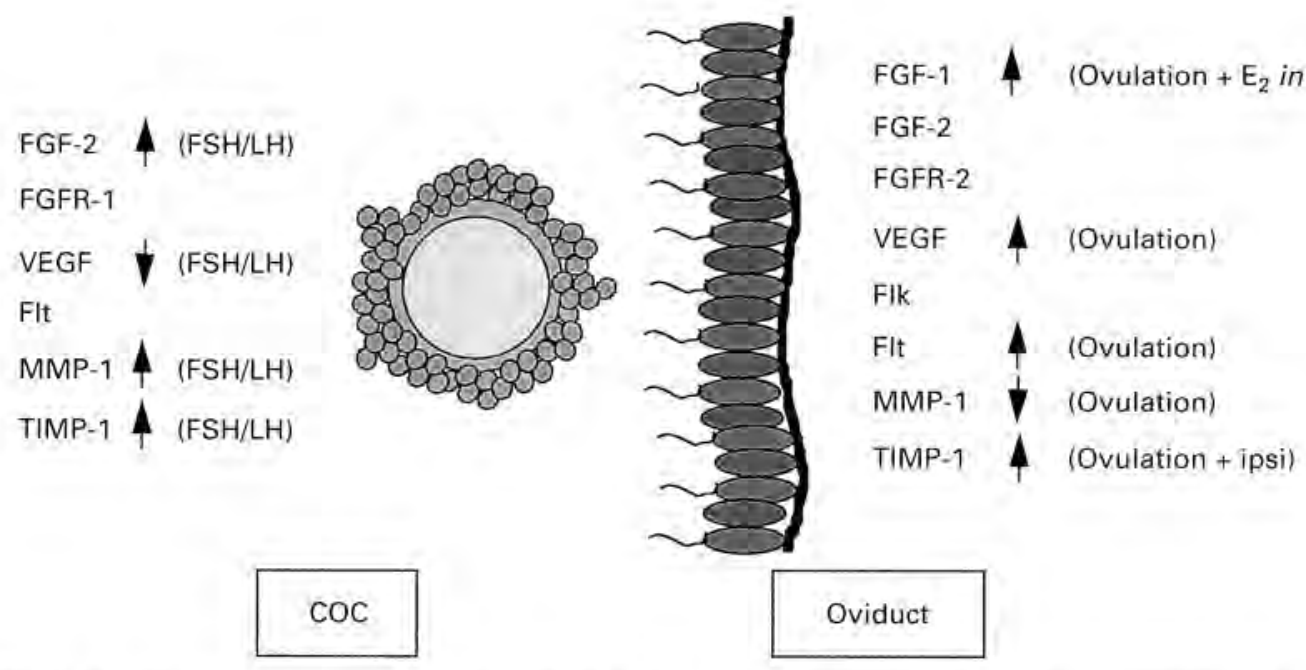

Fig. 4. Specific gene expression is identified in bovine cumulus-oocyte complexes (COC) and oviduct epithelium. Obvious regulation is increased $(\uparrow)$ or decreased $(\downarrow)$ amounts of mRNA after the FSH/LH surge, during ovulation, oestradiol-mediated ( $\mathrm{E}_{2}$ ) or in the ipsilateral oviduct (ipsi). FGF-1, fibroblast growth factor 1; FGF-2, fibroblast growth factor 2; FGFR-1, fibroblast growth factor receptor 1; FGFR-2, fibroblast growth factor 2; Flt/Flk, vascular endothelial growth factor (VEGF) receptors; MMP-1, matrix metalloproteinase 1; TIMP-1, tissue inhibitor of metalloproteinase 1 .

\section{Conclusions}

The FGF and VEGF growth factor systems were detected and the ECM components MMP-1 and TIMP-1 were expressed in a specific manner within ovarian follicles, the COC, and the oviduct. Species-specific and cycle-dependent variations in expression of growth factors were found especially correlated with the cell type (Gabler et al., 1997b). Specific distributions of different FGFR types indicate an important role of the receptor structure that is necessary for transducing intracellular signals (Bifkalvi et al., 1997). All known biological effects of the potent mitogenic FGFs are related to cellular differentiation, angiogenesis, wound healing and tumour growth (Gospodarowicz et al., 1987), whereas endothelial cells may be the target of VEGF to promote angiogenesis and permeability (Ferrara et al., 1992). Differentiation and nutritional support could be partly regulated by these growth factors within the ruminant and primate oviduct.

Furthermore, increased TIMP-1 expression could support an embryotrophic effect within the bovine oviduct (Gabler and Einspanier 1998). As summarized in Fig. 4, within the bovine oviduct many possible paracrine interactions between the COC and oviduct can be proposed. In addition, ECM components are directly connected to important reproductive responses by either liberating biologically active proteins from epithelial surfaces or changing sperm-surface structures (Einspanier et al., 1996). However, the selection and dominance of ovarian follicles may be influenced by growth factors as proposed for the FGF- and VEGF-systems (Kamhuber et al., 1997; Schams et al., 1997). The proposed paracrine cross-talk involving different growth factor and ECM 
systems leads to a complex network within the oviduct enabling alternating reaction cascades leading to an interesting fuzzy-logic approach (Horseman et al., 1997). Our results support such a concept of paracrine and autocrine interactions containing different growth factor and ECM systems with respect to a species-specific appearance in the mammalian oviduct. This enables a limited insight into the naturally occurring conditions for supporting the young embryo, and in the future the biological relevance of the proteins described will be further characterized.

We would like to thank S. Rode, K. Fuhrmann and A. Marten for technical help. This work was supported by grants of the DFG (Ei 296/4-2; Ei 296/6-1; Wo 663/1-1).

\section{References}

Adachi K, Kurachi H, Adachi H, Imai T, Sakata M, Homma H, Higashiguchi O, Yamamoto T and Miyake A (1995) Menstrual cycle specific expression of epidermal growth factor receptors in human fallopian tube epithelium journal of Endocrinology $147553-563$

Arias EB, Verhage HG and Jaffe RC (1994) Complementary deoxyribonucleic acid cloning and molecular characterization of an estrogen-dependent human oviductal glycoprotein Biology of Reproduction 51 685-694

Bifkalvi A, Klein S, Pintucci G and Rifkin DB (1997) Biological roles of libroblast growth factor-2 Endocrine Reviews 18 $26-44$

DeSouza MM and Murray MK (1995) An estrogen-dependent secretory protein, which shares identity with chitinases, is expressed in a temporally and regionally specific manner in the sheep oviduct at the time of fertilization and embryo development Endocrinology 136 2485-2496

Donnelly KM, Fazleabas and Verhage HG (1991) Cloning of a recombinant complementary DNA to a baboon estradioldependent oviduct-specific glycoprotein Molecular Endocrinology 5 356-364

Einspanier R, Gabler C and Lauer B (1996) Expression of urokinase plasminogen activator (UPA) is correlated with soluble heparin-analogues and basic fibroblast growth factor (bFGF) in bovine oviducts during oestrous cycle Journal of Reproduclion and Ferfility Abstract Series 17 Abstract 26

Einspanier R, Lauer B, Gabler C, Kamhuber M and Schams D (1997) Egg-cumulus-oviduct interactions and fertilization. In The Fate of the Male Germ Cell Advances in Experimental Medicine and Biology pp 279-289 Ed. R Ivell and Holstein. Plenum Press.

Ellington JE (1991) The bovine oviduct and its role in reproduction: a review of the literature Cornell Veterinatian $81313-328$

Ferrara N, Houck K, Jakeman L and Leung DW (1992) Molecular and biological properties of the VEGF family of proteins Endocrine Reviews 13 18-32

Gabler C and Einspanier R (1998) Increased expression of tissue inhibitor of metalloproteinase 1 (TIMP-1) during ovulation indicates its remarkable biological action in the bovine oviduct Experimental and Clinical Endocrinology and Diabetes 1068 (Abstract)

Gabler C, Lauer B, Einspanier A, Schams D and Einspanier R (1997a) Detection of mRNA and immunoreactive proteins for acidic and basic fibroblast growth factor and expression of the fibroblast growth factor receptor in the bovine oviduct Journal of Reproduction and Ferfility 109 213-221
Gabler C, Einspanier A and Einspanier R (1997b) Species-specific differences of growth factor expression in the female reproductive tract: FGF- and IGF-systems in primate versus bovine oviduct Reprofuction in Domestic Animals 32 7 (Abstract)

Gabler C, Plath-Gabler A, Einspanier A and Einspanier R (1998) The localization and expression of insulin-like growth factors, fibroblast growth factors, transforming growth factor alpha and their receptors indicate an auto-/paracrine influence in the oviduct of the common marmoset monkey (Call jacch) Biology of Reproduction 58 1451-1457

Gandolfi F, Brevini TAL and Moor RM (1989) Effects of oviduct environment on embryonic development Journal of Reproduction and Fertility 38 107-115

Gospodarowicz D, Ferrara N, Schweigerer L and Neufeld G (1987) Structural characterization and biological functions of FGF Endocrinc Review 8 95-114

Harvey MB, Arcellana-Panlilio MY, Zhang $X$, Schultz GA and Watson AJ (1995) Expression of genes encoding antioxidant enzymes in pre-implantation mouse and cow embryos and primary bovine oviduct cultures employed for embryo co-culture Biology of Reproduction 53 532-540

Horseman N, Engle S and Ralesca A (1997) The logic of signalling from the cell surface to the nucleus. Trends in Endocrinology and Metabolism 8 123-129

Hunter RH (1995) Human sperm reservoirs and Fallopian tube function: a role for the intra-mural portion? Acta Obstetrica et Gynecologia Scandinavia 74 677-681

Kamhuber M, Amselgruber W, Einspanier R and Schams D (1997) Possible role of growth factors for follicle selection during the bovine oestrous cycle Reproduction in Domestic Animals 328 (Abstract)

Lauer B and Einspaniex R (1996a) Cumulus expansion at the molecular level: expression of extracellular matrix components Archives of Animal Breeding, Dunmterstorf 3951 (Abstract)

Lauer B and Einspanier R (1996b) Are distinct levels of soluble heparin-analogues responsible for different alterations of sperm in the bovine oviduct? Experimental and Clinical Endocrinology and Diabetes 104131 (Abstract)

Lauer B, Wollenhaupt K and Einspanier R (1995) Detection of a new estradiol-mediated bovine oviduct protein and sperm-oviduct interactions using a tissue-perfusion system Journat of Reproduction and Fertility Abstract Series 15 Abstract 94

Levebvre R, Chenoweth PJ, Drost M, LeClear CT, MacCubbin M, Dutton JT and Suarez SS (1995) Characterization of the oviductal sperm reservoir in cattle Biology of Reproduction 53. $1066-1074$ 
Monniaux D, Huet C, Besnard N, Clement F, Bosc M, Pisselet C, Monget P and Mariana JC (1997) Follicular growth and ovarian dynamics in mammals Joumal of Reproduction and Fertility 51 3-23

Plath A, Krause I and Einspanier R (1997) Species identification in dairy products by three different DNA-based techniques Zeitschrift Lebensmittel Lintersuchung Forschung $A$ $205437-441$

Satoh T, Kobayashi K, Yamashita S, Kikuchi M, Sendai $\mathrm{Y}$ and Hoshi H (1994) Tissue inhibitor of metalloproteinases (TIMP-1) produced by granulosa and oviduct cells enhances in vitro development of bovine embryo Biology of Reproduction 50 835-844

Schams D, Kamhuber M and Einspanier R (1997) Expression changes of growth factors, receptors and $\mathrm{P} 450$-aromatase during recruitment, selection and dominance of bovine follicles Biology of Reproduction 56169 (Abstract)

Sendai $Y$, Komiya H, Suzuki K, Onuma T, Kikuchi M, Hoshi $\mathrm{H}$ and
Araki Y (1995) Molecular cloning and characterization of a mouse oviduct-specific glycoprotein Biology of Reproduction $53285-294$

Spom MB and Roberts AB (1988) Peptide growth factors are multifunctional Nature 332 217-219

Tadakuma H, Okamura H, Kitaoka M, lyama $\mathrm{K}$ and Usuku G (1993) Association of immunolocalization of matrix metalloproteinase 1 with ovulation in hCG-treated rabbit ovary Journal of Reproduction and Fertility 98 503-508

Wollenhaupt K, Tiemann U, Einspanier R, Sclneider F, Kanitz W and Brüssow KP (1997) Characterization of the epidermal growth factor receptor (EGF-R) in the pig oviduct and endometrium lourral of Reproduction and Fertility 111 173-181

Wollenhaupt K, Gabler C, Einspanier R and Schneider F (1998) Regulation of the EGF/EGF-R-system in the endometrium of early pregnant pigs Reproduction in Domestic Animals 5 154 (Abstract) 